Gut,, 1979, 20, 763-768

\title{
Gastric acid secretion in uraemia and circulating levels of gastrin, somatostatin, and pancreatic polypeptide ${ }^{1}$
}

\author{
R. HÄLLGREN, J. LANDELIUS, K-E. FJELLSTRÖM, AND G. LUNDQVIST ${ }^{2}$ \\ From the Departments of Internal Medicine, Clinical Physiology, and Clinical Chemistry, \\ University Hospital, Uppsala, Sweden
}

SUMMARY Basal circulating levels of gastrin, somatostatin, and pancreatic polypeptide were measured in 30 chronic haemodialysis patients. Five patients had considerably raised serum gastrin ( $>400 \mathrm{pmol} / 1)$ and also gastric achlorhydria while $75 \%$ of the patients who had normal $(<55 \mathrm{pmol} / 1)$ or moderately increased $(<400 \mathrm{pmol} / 1)$ serum gastrin had raised maximal acid outputs. Patients with serum gastrin $>400 \mathrm{pmol} / 1$ had significantly lower plasma concentrations of somatostatin compared with both healthy individuals and uraemic patients with normal gastrin levels. Raised serum concentrations of pancreatic polypeptide were observed in the majority of the patients but no correlation was found between this peptide and gastric acid secretion or circulating levels of gastrin and somatostatin, respectively. Prolonged circulation time for gastrin and pancreatic polypeptide was demonstrated after food stimulation. Prolonged gastrin stimulation of the parietal cell mass may lead to work hypertrophy and gastric acid hypersecretion. Whether long-standing overstimulation by gastrin also may induce atrophy of the cells remains to be studied.

Raised levels of circulating gastrin are frequently observed in patients with chronic end-stage renal failure (Dent et al., 1972; Korman et al., 1972; Hällgren et al., 1978). However, the clinical importance and the biological relevance of raised immunoreactive gastrin in renal failure are uncertain because of lack of information concerning gastric secretion. The main purpose of the present study was to measure serum gastrin levels in uraemic patients on maintenance dialysis and to correlate the measurements with acid secretion data. Although clinical and experimental evidence indicates a central role for the kidney in the elimination of gastrin from the circulation (for review: Walsh and Grossman, 1975) previous observations suggest that basal circulating gastrin levels in uraemia are moderated to a major extent by extrarenal mechanisms (Hällgren et al., 1978). The second aim of this investigation was to determine whether circulating somatostatin

'Supported by Carin Trygger Foundation and Swedish Medical Research Council.

${ }^{2}$ Address for correspondence: Dr. Gudmar Lundqvist, Department of Clinical Chemistry, University Hospital, S-750 14 Uppsala, Sweden.

Received for publication 2 April 1979. or pancreatic polypeptide (PP) were involved in the homeostasis of gastrin in uraemia, as intravenous administration of both these gastropancreatic hormones is known to inhibit gastric acid secretion and somatostatin is also found to reduce the plasma gastrin concentration (Bloom et al., 1974; Lin and Chance, 1974).

\section{Methods}

Thirty patients (16 males, 14 females, mean age 46 years, range 18-64 years) with end stage renal disease were evaluated. All patients had an endogenous creatinine clearance of less than 3 $\mathrm{ml} / \mathrm{min}$. The diagnoses of the patients, their approximate period of renal insufficiency, and their time on dialysis are seen in Tables 1 to 3. All patients were on an ambulatory dialysis programme, and the treatment comprised an average of 10 hours per week in two sessions of equal length using Gambro coil dialysers.

\section{GASTRIC ACID SECRETION}

Investigations were carried out between 24 and 48 hours preceding the haemodialysis. Informed consent was obtained from 16 of the patients. After an 
Table 1a Clinical features of azotaemic patients with S-gastrin $(<55$ pmolll)

\begin{tabular}{|c|c|c|c|c|c|}
\hline Patient & $\begin{array}{l}\text { Age } \\
(y r)\end{array}$ & Sex & $\begin{array}{l}\text { Renal failure } \\
\text { duration } \\
(y r)\end{array}$ & $\begin{array}{l}\text { Dialysis } \\
\text { duration } \\
\text { (months) }\end{array}$ & $\begin{array}{l}\text { Diagnosis of } \\
\text { renal diagnosis }\end{array}$ \\
\hline $\begin{array}{l}\text { S.A. } \\
\text { B.O. } \\
\text { G.H. } \\
\text { V.H. } \\
\text { J.EL. } \\
\text { L.E. } \\
\text { M.LG. } \\
\text { T.L. } \\
\text { S.P. }\end{array}$ & $\begin{array}{l}34 \\
51 \\
57 \\
50 \\
32 \\
17 \\
31 \\
32 \\
50\end{array}$ & $\begin{array}{l}\mathbf{M} \\
\mathbf{M} \\
\mathbf{F} \\
\mathbf{F} \\
\mathbf{M} \\
\mathbf{F} \\
\mathbf{F} \\
\mathbf{M} \\
\mathbf{M}\end{array}$ & $\begin{array}{l}1,5 \\
2 \\
6 \\
12 \\
1,5 \\
2,5 \\
2 \\
2 \\
3\end{array}$ & $\begin{array}{r}5 \\
8 \\
3 \\
32 \\
2 \\
13 \\
11 \\
3 \\
1\end{array}$ & $\begin{array}{l}\text { Glomerulonephritis } \\
\text { Glomerulonephritis } \\
\text { Glomerulonephritis } \\
\text { Glomerulonephritis } \\
\text { Glomerulonephritis } \\
\text { Nephrocalcinosis } \\
\text { Cortical necrosis } \\
\text { Diabetic nephropathy } \\
\text { Diabetic nephropathy }\end{array}$ \\
\hline$\overline{\mathbf{X}} \pm \mathbf{S E M}$ & $39 \cdot 3 \pm 4 \cdot 4$ & & $3 \cdot 6 \pm 1 \cdot 1$ & $8 \cdot 7 \pm 3 \cdot 2$ & \\
\hline
\end{tabular}

Table 1b Laboratory findings in azotaemic patients with fasting S-gastrin $(<55$ pmol/l)

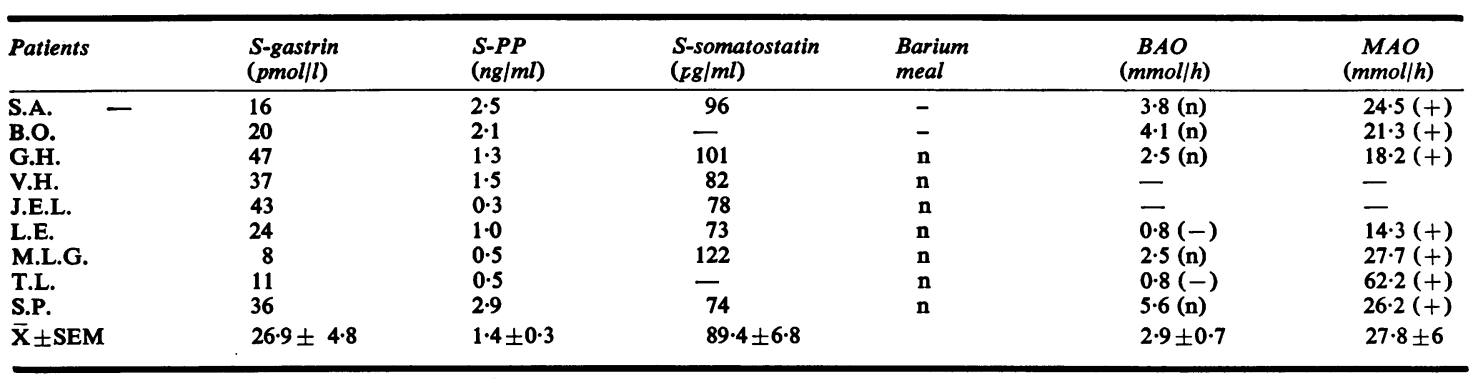

n: normal.

$(+)$ : raised.

(-): decreased.

Table 2a Clinical features of azotaemic patients with S-gastrin (55-400 pmol/l)

\begin{tabular}{|c|c|c|c|c|c|}
\hline Patient & $\begin{array}{l}\text { Age } \\
(y r)\end{array}$ & Sex & $\begin{array}{l}\text { Renal failure } \\
\text { duration } \\
(y r)\end{array}$ & $\begin{array}{l}\text { Dialysis } \\
\text { duration } \\
\text { (months) }\end{array}$ & $\begin{array}{l}\text { Diagnosis of } \\
\text { renal disease }\end{array}$ \\
\hline $\begin{array}{l}\text { R.E. } \\
\text { R.F. } \\
\text { G.P. } \\
\text { R.A. } \\
\text { P.H. } \\
\text { M.J. } \\
\text { K.G.A. } \\
\text { H.N. } \\
\text { K.N. } \\
\text { A.O. } \\
\text { B.A. } \\
\text { A.K. } \\
\text { B.L. } \\
\text { S.E. } \\
\text { B.C. } \\
\text { X. } \pm \text { SEM }\end{array}$ & $\begin{array}{l}32 \\
45 \\
54 \\
24 \\
50 \\
48 \\
50 \\
46 \\
45 \\
48 \\
55 \\
32 \\
60 \\
49 \\
37 \\
45 \pm 9 \cdot 8\end{array}$ & $\begin{array}{l}\mathbf{M} \\
\mathbf{M} \\
\mathbf{M} \\
\mathbf{M} \\
\mathbf{M} \\
\mathbf{F} \\
\mathbf{M} \\
\mathbf{F} \\
\mathbf{F} \\
\mathbf{M} \\
\mathbf{M} \\
\mathbf{M} \\
\mathbf{F} \\
\mathbf{M} \\
\mathbf{F}\end{array}$ & $\begin{array}{l}5 \\
2 \\
2 \\
7 \\
12 \\
5 \\
6 \\
5 \\
6 \\
0,8 \\
5 \\
2 \\
5 \\
7 \\
0.5 \\
4 \cdot 7 \pm 0.8\end{array}$ & $\begin{array}{c}1 \\
11 \\
3 \\
7 \\
12 \\
38 \\
48 \\
36 \\
3 \\
4 \\
3 \\
1 \\
11 \\
19 \\
1 \\
13 \cdot 2 \pm 3.9\end{array}$ & $\begin{array}{l}\text { Diabetic nephropathy } \\
\text { Glomerulonephritis } \\
\text { Polycystic kidneys } \\
\text { Pyelonephritis } \\
\text { Glomerulonephritis } \\
\text { Polycystic kidneys } \\
\text { Glomerulonephritis } \\
\text { Pyelonephritis } \\
\text { Glomerulonephritis } \\
\text { Nephrosclerosis } \\
\text { Polycystic kedneys } \\
\text { Diabetic nephropathy } \\
\text { Pyelonephritis } \\
\text { Glomerulonephritis } \\
\text { Glomerulonephritis }\end{array}$ \\
\hline
\end{tabular}

overnight fast a nasogastric tube (Salem Sump Tube No $14,120 \mathrm{~cm}$ ) was positioned in the pyloric antrum and the stomach was completely emptied. Positional control was made by a $90 \%$ recovery of $50 \mathrm{ml}$ of saline through the tube. Continuous suction was then applied, the adhesion of gastric mucosa to the tube openings being prevented by the construction of the tube, which allowed room air to be aspirated by the negative pressure produced by the pump.

Basal secretion was obtained by measuring the collected juice every 15 minutes for one hour and basal acid output (BAO) was expressed as the mean of the four 15-minute periods and expressed as mmol hydrochloric acid per hour.

Pentagastrin ( $6 \mu \mathrm{g}$ per $\mathrm{kg}$ bw, subcutaneously) was administered and the gastric juice was collected for at least six more 15 minute periods or until the titrated total acid secretion had passed its maximum by at least two 15 minute periods of collection. Maximal acid output (MAO) was expressed as the mean of the four continuous 15 minute periods showing the largest amount of total acid secretion in 
Table 2b Laboratory findings in azotaemic patients with fasting S-gastrin (55-400 pmol/l)

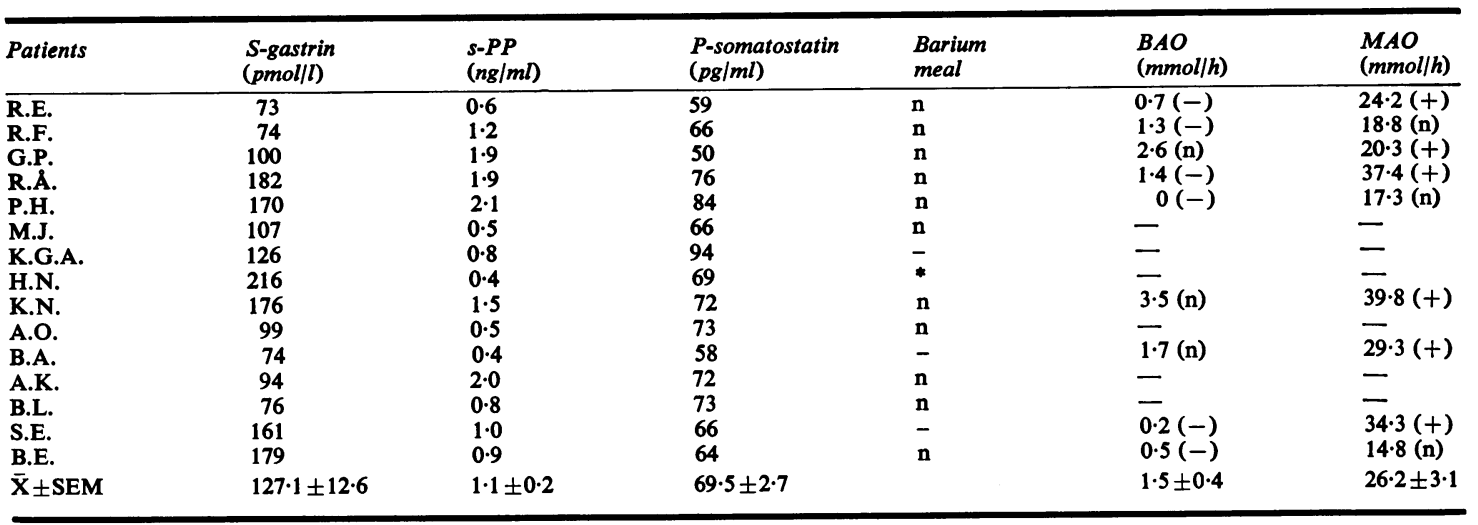

*Antrum resection was performed in 1975.

n: normal.

$(+)$ : raised.

(-): decreased.

Table 3a Clinical features of azotaemic patients with $S$-gastrin ( $400 \mathrm{Pmol} / \mathrm{l}$ )

\begin{tabular}{|c|c|c|c|c|c|}
\hline Patient & $\begin{array}{l}\text { Age } \\
(y r)\end{array}$ & Sex & $\begin{array}{l}\text { Renal failure } \\
\text { duration } \\
(y r)\end{array}$ & $\begin{array}{l}\text { Dialysis } \\
\text { duration } \\
\text { (months) }\end{array}$ & $\begin{array}{l}\text { Diagnosis of } \\
\text { renal disease }\end{array}$ \\
\hline $\begin{array}{l}\text { K.J. } \\
\text { A.N. } \\
\text { E.E. } \\
\text { R.E. } \\
\text { G.B.J. } \\
\text { C.J. }\end{array}$ & $\begin{array}{l}41 \\
63 \\
6 ? \\
64 \\
41 \\
29\end{array}$ & $\begin{array}{l}\mathbf{F} \\
\mathbf{M} \\
\mathbf{F} \\
\mathbf{F} \\
\mathbf{F} \\
\mathbf{F}\end{array}$ & $\begin{array}{l}3 \cdot 5 \\
1 \cdot 5 \\
5 \\
5 \\
4 \\
1 \cdot 5\end{array}$ & $\begin{array}{r}8 \\
1 \\
2 \\
19 \\
1 \\
12\end{array}$ & $\begin{array}{l}\text { Glomerulonephritis } \\
\text { Glomerulonephritis } \\
\text { Pyelonephritis } \\
\text { Pyelonephritis + diabetes mellitus } \\
\text { Diabetic nephropathy } \\
\text { Diabetic nephropathy }\end{array}$ \\
\hline$\overline{\mathbf{X}} \pm \mathbf{S E M}$ & $50 \cdot 2 \pm 6 \cdot 2$ & & $3.4 \pm 0.7$ & $7 \cdot 2 \pm 3 \cdot 0$ & \\
\hline
\end{tabular}

Table 3b Laboratory findings in azotaemic patients with fasting $S$-gastrin ( $>400$ pmol/l)

\begin{tabular}{|c|c|c|c|c|c|c|}
\hline Patients & $\begin{array}{l}\text { S-gastrin } \\
(\mathrm{pmol} / \mathrm{l})\end{array}$ & $\begin{array}{l}S-P P \\
(n g / m l)\end{array}$ & $\begin{array}{l}\text { P-somatostatin } \\
(\mathrm{pg} / \mathrm{ml})\end{array}$ & $\begin{array}{l}\text { Barium } \\
\text { meal }\end{array}$ & $\begin{array}{l}B A O \\
(\mathrm{mmol} / \mathrm{h})\end{array}$ & $\begin{array}{l}M A O \\
(\mathrm{mmol} / \mathrm{h})\end{array}$ \\
\hline $\begin{array}{l}\text { K.J. } \\
\text { A.N. } \\
\text { E.E. } \\
\text { R.E. } \\
\text { G.B.J. } \\
\text { C.J. }\end{array}$ & $\begin{array}{r}1242 \\
545 \\
1816 \\
2254 \\
656 \\
457\end{array}$ & $\begin{array}{l}0.6 \\
1.0 \\
1.7 \\
0.9 \\
0.2 \\
0.5\end{array}$ & $\begin{array}{l}49 \\
44 \\
55 \\
59 \\
64 \\
63\end{array}$ & $\begin{array}{l}\mathbf{n} \\
\mathbf{n} \\
- \\
\mathbf{n} \\
\mathbf{n} \\
-\end{array}$ & $\begin{array}{l}0 \\
0 \\
0 \cdot 2 \\
0 \\
0 \\
0\end{array}$ & $\begin{array}{l}0 \\
0 \\
0 \cdot 2 \\
0 \\
0 \\
0\end{array}$ \\
\hline
\end{tabular}

terms of mmol hydrochloric acid per hour.

The gastric juice was titrated with $0 \cdot 1$ molar $\mathrm{NaOH}$ to $\mathrm{pH} 7.0$ using an automatic titrator (Radiometer, Copenhagen).

Normal values for BAO in this laboratory are considered to be $1.5-5.9 \mathrm{mmol}$ per hour for men and 0.4-4.0 mmol per hour for women. The MAO values that were obtained were compared with normal values based on rearrangements of computerised normal range for MAO based on age, sex, and weight as presented by Blackman et al. (1970).

About $5 \mathrm{ml}$ of each neutralised aliquot of gastric juice was immediately chilled to $4^{\circ} \mathrm{C}$. The chilled samples were then placed for 10 minutes in a water bath at $100^{\circ} \mathrm{C}$. After centrifugation at $+4^{\circ} \mathrm{C}$ the samples were frozen at $-20^{\circ} \mathrm{C}$ until gastrin and somatostatin analyses.

\section{PROTEIN-RICH TEST MEAL}

After an overnight fast six patients selected with respect to serum gastrin levels had a standardised protein-rich test meal. Venous blood samples were obtained from an indwelling needle immediately before and at regular intervals during and up to 120 
minutes after the meal. The samples were collected according to the procedures described below and analysed for the concentration of gastrin, pancreatic polypeptide, and somatostatin.

X-ray examinations of the stomach were performed in the standard fashion.

\section{RADIOIMMUNOCHEMISTRY}

After an overnight fasting period and immediately before start of dialysis venous blood specimens for gastrin and PP were obtained. For somatostatin determinations venous blood was collected in chilled tubes with the addition of heparin (143 USP units) and Trasylol (400 KIE per ml of blood). After centrifugation at $+4^{\circ} \mathrm{C}$, serum and plasma respectively were stored at $-20^{\circ} \mathrm{C}$ until analyses in sequence were performed.

Gastrin and PP were determined using radioimmunoassay procedures reported earlier (Lundqvist and Wide, 1977; Hällgren et al., 1977). PP-antiserum was a gift from Dr R. E. Chance, Eli Lilly and Co, Minneapolis, while antigastrin serum was a gift from Professor J. Rehfeld, Aarhus, Denmark. Normal circulating levels for gastrin and PP at our laboratory are $<55 \mathrm{pmol} / \mathrm{l}$ and $<0.4 \mathrm{ng} / \mathrm{ml}$, respectively. Plasma somatostatin was measured after extraction of samples with petroleum-ether-acetone with a solid phase technique recently described (Arimura et al., 1978; Lundqvist et al., 1979a), while the gastric juice samples were assayed with the same technique but without the extraction procedure. Synthetic Tyr $^{1}$ somatostatin (Beckman, Geneva) was used for preparation of tracer, and synthetic somatostatin (Beckman, Geneva) was used for preparation of standards. The antiserum used, R 141, was a gift from Dr R. Elde, Minneapolis, and had been characterised earlier (Arimura et al., 1978; Lundqvist et al., 1978). Normal values of plasma somatostatin are $77 \pm 19$ (SD) $\mathrm{pg} / \mathrm{ml}$ (Lundqvist et al., 1979a).

\section{Results}

On the basis of their fasting gastrin levels, the patients were divided into three subgroups: group I consisted of nine patients who had gastrin levels within the normal range ( $<55 \mathrm{pmol} / \mathrm{l})$; group II of 15 individuals with moderately increased levels (73-216 $\mathrm{pmol} / \mathrm{l})$; and group III $(\mathrm{n}=6)$ with considerably raised gastrin levels (457-2254 pmol/1). Clinical and laboratory data on the patients are listed in Tables 1 to 3 . Renal diagnoses were distributed similarly in the three groups. The mean age of the patients in group I (mean age 39 years) was lower than in groups II (mean age 45 years) and III (mean age 50 years), but the differences were not significant. While a low or normal BAO was found in the patients of groups I and II, $75 \%$ of them had an increased MAO compared with healthy individuals of the same age

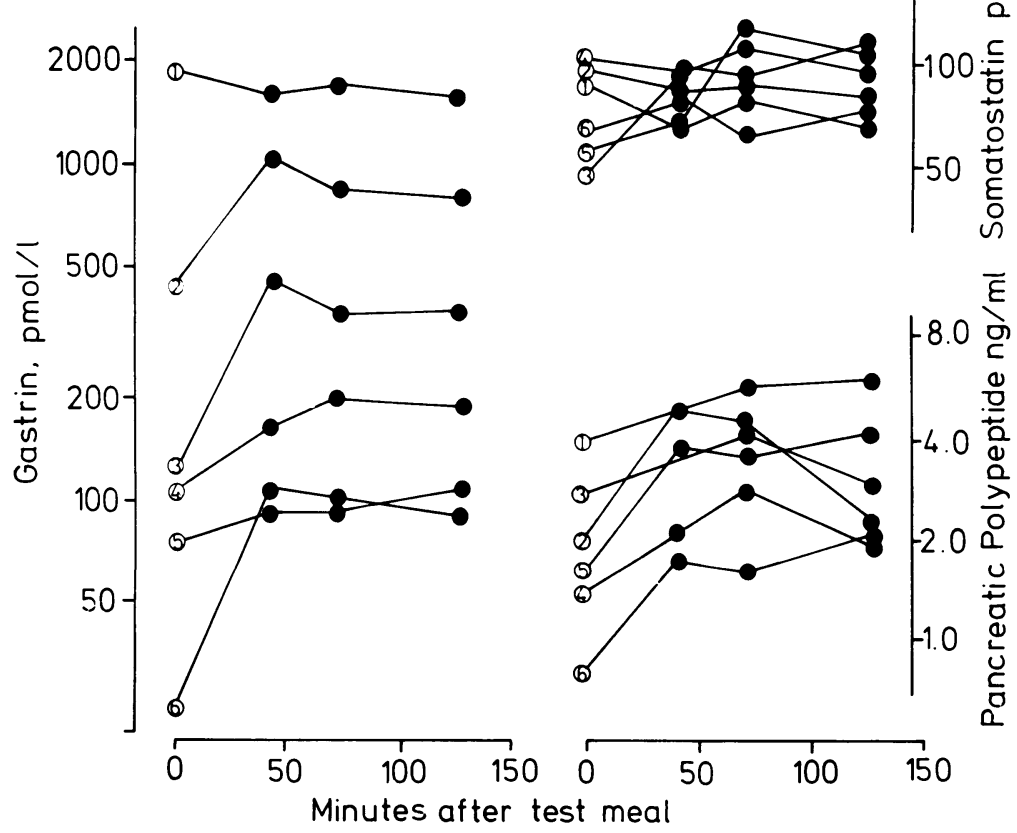


and sex. In group III all patients investigated had achlorhydria or advanced hypochlororhydria. No relationship was found between the basal gastrin level or the gastric acid secretory function and the time period in dialysis or the known predialysis period of renal insufficiency. No patient had radiological evidence of peptic ulceration. Raised serum concentrations of $\mathrm{PP}$ were observed in the majority of uraemic patients. No significant difference of the mean of this hormone was found between groups I-III. Plasma somatostatin was not raised in the patients compared with the reference group of healthy individuals. However, the mean somatostatin levels varied significantly between the groups:

Somatostatin/plasma, $\mathrm{pg} / \mathrm{ml}$

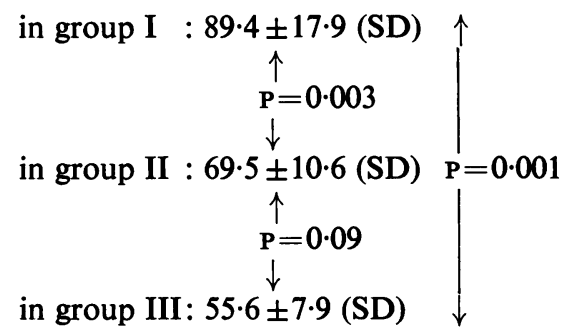

Circulating levels of gastrin, PP, and somatostatin after a standardised meal were measured in six of the uraemic patients. The results, which are presented in the Figure, indicate that uraemic patients respond to physiological stimuli with an increase of serum gastrin and pancreatic polypeptide sustained for more than two hours after food intake. The pattern of serum gastrin or polypeptide response to food stimulation was similar, irrespective of the basal serum levels of the hormones with one exception. In one patient who had the highest fasting gastrin levels (at $2000 \mathrm{pmol} / \mathrm{l}$ ), no further increment of gastrin was observed. The degree of variations of plasma somatostatin found after the test meal are within the intra-day variation observed in healthy individuals.

No gastrin or somatostatin immunoreactivity could be detected in the samples of gastric juice.

\section{Discussion}

In the present report we confirm our previous observations on basal circulating levels of gastrin, PP, and somatostatin in patients with chronic uraemia and on maintenance dialysis (Hällgren et al., 1977; Hällgren et al., 1978; Lundqvist et al., 1979b). About $30 \%$ of uraemic patients have serum gastrin concentrations within the normal range and the others have either moderately or considerably raised levels. Serum pancreatic polypeptide is raised in patients with end-stage renal failure with its mean about five times the normal level. After food stimulation uraemic patients react like healthy individuals (Walsh and Grossman, 1975; Adrian et al., 1976) with an increase of circulating gastrin and PP. Evidently both these hormones are mainly eliminated from circulation by the kidneys. The routes of catabolism of plasma somatostatin, which is not raised in uraemia, are unknown, but experimental studies in animals suggest that the liver is involved (Ensinck et al., 1976). Other routes of elimination of gastrin and somatostatin have been suggested by UvnäsWallensten and colleagues (1977) who detected large amounts of both these hormones in the gastric juice of anaesthetised cats. In the present study we were unable to detect any gastrin or somatostatin immunoreactivity in the gastric juice of the patients at rest or after pentagastrin stimulation. These findings might indicate that gastrin and somatostatin are not eliminated by the stomach in man. Alternatively, in spite of our precautions, the hormones had been degraded in the analysed gastric juice samples.

The biological significance of increased serum levels of gastrin in uraemia has previously been speculated upon. In our study $20 \%$ of the patients had a marked hypergastrinaemia ( $>400 \mathrm{pmol} / \mathrm{l})$ and also achlorhydria, suggesting atrophic gastritis of the antrum sparing type. These patients had also significantly lower plasma concentrations of somatostatin compared with both healthy individuals and uraemic patients with normal gastrin levels, which might indicate that circulating gastrin depresses the release of somatostatin into the circulation.

In patients with normal or moderately increased fasting gastrin concentrations we observed an adequate or decreased BAO and in the majority of cases a raised MAO compared with the reference group in accordance with previous investigators (Ventkateswaran et al., 1972; Shepherd et al., 1973; Sullivan et al., 1976). It is reasonable to attribute the observed hypersecretory state to an increased parietal cell mass. The well-documented prolonged gastrin response in uraemia after food ingestion (Sullivan et al., 1976), as also reported in this paper, might be the mechanism stimulating the hypertrophy of the acid-producing cells.

Such hypertrophy is seen in patients with Zollinger-Ellison syndrome and can also be experimentally induced by pentagastrin over a period of time. Whether long-standing overstimultaion by gastrin also might induce atrophy_perhaps after an initial phase of hypertrophy-of the parietal cells is unknown. Such speculation has support in other endocrine systems where certain hormones-for example, gonadotropins-in high amounts are postulated to cause atrophy of the target cells 
(Lundberg et al., 1978). Another question arises: why is the basal gastric acid secretion not increased in those uraemic patients who have hypergastrinaemia and signs of increased parietal cell mass? One possible explanation might be the neutralising effect of a high gastric ammonia content in uraemia (von Korff et al., 1951). Alternatively, there might be a decreased parietal cell sensitivity to gastrin or a competitive inhibition of gastrin activity by other substances raised in situations with impaired renal function as proposed by McConnell et al (1975). PP might be such a substance, as it is known to inhibit pentagastrin stimulated gastric secretion (Lin and Chance, 1974). It is reasonable to assume that the highly raised serum concentrations of this hormone in uraemia moderate the acid secretion in spite of the lack of correlation between serum PP and MAO and BAO respectivley or basal serum gastrin.

Raised maximal gastric acid secretion might certainly contribute to the increased incidence of peptic ulceration-not infrequently with a fatal outcome-reported for patients with uraemia (Hampers et al., 1973). Renal transplantation additionally increases the risk of gastrointestinal bleeding (Gurland et al., 1973). Measurement of plasma gastrin seems to be a valuable method for detecting achlorhydria in uraemia and might thereby reduce the number of other extensive investigations recommended to detect those uraemic patients most liable to develop gastric complications.

\section{References}

Adrian, T. E., Bloom, S. R., Bryant, M. G., Polak, J. M., Heitz, P., and Barnes, A. J. (1976). Distribution and release of human pancreatic polypeptide. Gut, 17, 940-944.

Arimura, A., Lundqvist, G., Rothman, J., Chang, R., Fernandez-Durango, R., Elde, R., Coy, D H., Meyers, C., and Schally, A. V. (1978). Radioimmunoassay of somatostatin. Metabolism, 27, suppl. 1, 1139-1144.

Blackman, A. H., Lambert, D. L., Thayer, W. R., Martin, H. F. (1970). Computed normal values for peak acid output based on age, sex and body weight. American Journal of Digestive Diseases, 15, 783-789.

Bloom, S. R., Mortimer, C. H., Thorner, M. O., Besser, G. M., Hall, R., Gomez-Pan, A., Roy, V. M., Russel, R. C. G. Coy, D. H., Kastin, A. J., and Schally, A. V. (1974). Inhibition of gastrin and gastric acid secretion by growthhormone release inhibiting hormone. Lancet, 2, 1106-1109.

Dent, R. I., Hirsch, H., James J. H., and Fischer, J. E. (1972). Hypergastrinemia in patients with acute renal failure. Surgical Forum, 23, 312-313.

Ensinck, J. W., Laschansky, E., Knoeber, M., Johnson, D., Benson, J., and Goodner, C. J. (1976). Distribution of somatostatin (5) measured by radioimmunoassay. (Abstract). Clinical Research, 24, 155A.

Gurland, H. J., Brunner, F. P., v Dehn, H., Harlen, H., Parsons, F. M., and Schärer, K. (1973). Combined report on regular dialysis and transplantation in Europe, III, 1972. Proceedings of the European Dialysis and Transplant Association, 10, xvii-lvii.

Hällgren, R., Karlsson, F. A., and Lundqvist, G. (1978). Serum level of immunoreactive gastrin: influence of kidney function. Gut, 19, 207-213.

Hällgren, R., Lundqvist, G., and Chance, R. E. (1977). serum levels of human pancreatic polypeptide in renal disease. Scandinavian Journal of Gastroenterology, 12, 923-927.

Hampers, C. L., Schupak, E., Lowrie, G. T., and Larusza, J. M. (1973). The gastrointestinal system. In Long-Term Haemodialysis: the Management of the Patient with Chronic Renal Failure. pp. 136-154. Grune and Stratton: New York.

Korman, M. G., Laver, M. C., and Hansky, J (1972). Hypergastrinaemia in chronic renal failure. British Medical Journal, 1, 209-210.

Lin, T. M., and Chance, R. E. (1974). Pancreatic polypeptide. In Endocrinology of the Gut, p. 143. Edited by W. Y. Chey, F. P. Brooks. C. R. Slack: Thorofare, New Jersey.

Lundberg, P. O., Nilsson A-C, and Wide, L. (1978). Hypergonadotrophic hypogonadism in oligophrenia. Acta Medica Scandinavia, 204, 115-121.

Lundqvist, G., Gustavsson, S., Elde, R., and Arimura, A. (1979a). A radioimmunosorbent assay for plasma somatostatin. Submitted to Clinica Chimica Acta.

Lundqvist, G., Gustavsson, S., and Hällgren, R. (1979b). Plasma levels of somatostatin-like immunoreactivityindependence of kidney function. Clinical Endocrinology. In press.

Lundqvist, G., and Wide, L. (1977). Serum gastrin determination with a radioimmunosorbent technique. Clinica Chimica Acta, 79, 357-362.

McConnell, J. B., Thjodleifsson, B., Stewart, W. K., and Wormsley, K. G. (1975). Gastric function in chronic renal failure. Effects of maintenance haemo dialysis. Lancet, 2, 1121-1123.

Shepherd, A. M. M., Stewart, W. K., and Wormsley, K. G. (1973). Peptic ulceration in chronic renal failure. Lancet, 1 1357-1359.

Sullivan, S. N., Tustanoff, E., Slaughter, D. N., Linton, A. L., Lindsay, R. M., and Watson, W. C. (1976). Hypergastrinemia and gastric acid hypersecretion in uremia. Clinical Nephrology, 5, 25-28.

Uvnäs-Wallensten, K., Efendic, S., and Luft, R. (1977). Vagal release of somatostatin into the antral lumen of cats. Acta Physiologica Scandinavia, 99, 126-128.

Ventkateswaran, P. S., Jeffers, A., Hocken, A. G. (1972). Gastric acid secretion in chronic renal failure. British Medical Journal, 4, 22-23.

Von Korff, R. W., Ferguson, D. J., and Glick, D.(1951). Role of urease in the gastric mucosal. 3. Plasma urea as source of ammonium ion in gastric juice of histaminestimulated dogs. American Journal of Physiology, 165, 695-700.

Walsh, J. H., and Grossman, M. I. (1965). Gastrin. New England Journal of Medicine, 292, 1324-1334. 